\title{
STUDY ON EXTRACTION PROCESS OF SUNFLOWER (HELIANTHUS ANNUUS L.) DRY WASTES USING DIFFERENT SOLVENTS
}

\author{
Olga Morarescu, Marina Grinco, Ion Dragalin, Veaceslav Kulcițki, Nicon Ungur* \\ Institutul de Chimie al Academiei de Ştiințe a Moldovei, 3, Academiei str., Chisinau MD-2028, Republic of Moldova \\ *e-mail: nicon.ungur@gmail.com,phone/fax: (+373 22) 739775
}

\begin{abstract}
The content of known tetra- and pentacyclic diterpenoids in extracts of sunflower (Helianthus annuus L.) dry wastes has been studied using different solvents for extraction. It was established that the largest extracted quantity of ent-kaur-16-en-19-oic acid is obtained when ethanol and diethyl ether are used for extraction of the plant material.
\end{abstract}

Keywords: ent-kaur-16-en-19-oic acid, 15 -angeloyl-ent-kaur-16-en-19-oic acid, ent-trachiloban-19-oic acid, diterpene, extraction.

\section{Introduction}

The scientific interest for tetracyclic diterpenic ent-kaur-16-en-19-oic (1a) and 15-angeloyl-ent-kaur-16-en-19oic (2a) acids, as well as for pentacyclic ent-trachiloban-19-oic acid (3a) can be explained by their broad spectrum of biological activities.

The ent-kaur-16-en-19-oic acid (1a) is an intermediate in the biogenetical scheme of gibberellic acids, which are relevant plant growth regulators [1]. Compound (1a) was isolated from different vegetal sources, especially from sunflower (Helianthus sp). [2-12]. We have achieved isolation of acids 1a-3a from the integral sunflower (Helianthus annuus L.) dry wastes $[13,14]$.

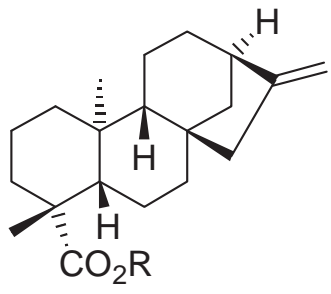

$1 \mathrm{a} \mathrm{R}=\mathrm{H}$

1b $\mathrm{R}=\mathrm{Me}$

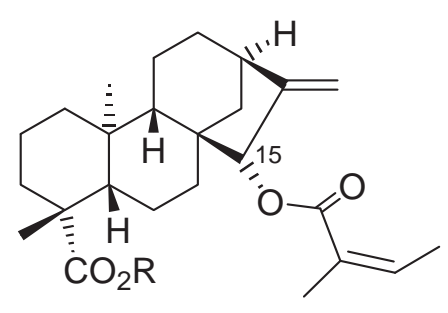

2a $\mathrm{R}=\mathrm{H}$

2b $\mathrm{R}=\mathrm{Me}$

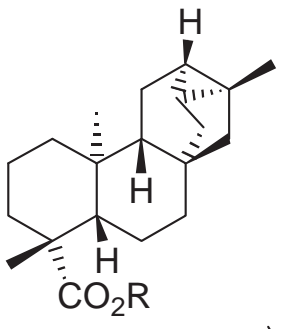

$3 a \mathrm{R}=\mathrm{H}$

3b $\mathrm{R}=\mathrm{Me}$

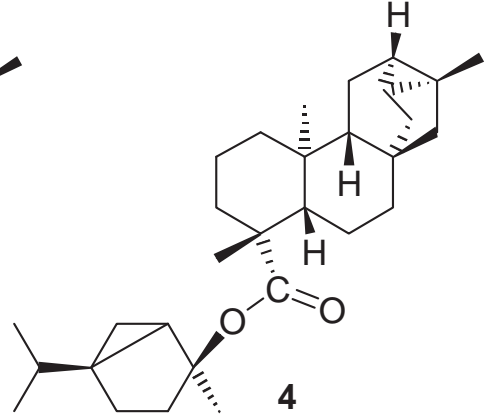

4

It is noteworthy to mention, that ent-kaur-16-en-19-oic acid (1a) was reported as an inhibitor of protein tyrosine phosphatase 1B (PTP1B) and was used as remedy for treatment of type 2 diabetes and obesity [15]. It also showed selective and significant cytotoxicity for MCF-7 [16], SF-268, MCF-7 and HepG2 cell lines [9], and exhibited inhibitory activity against the enzymes prolyl endopeptidase (PEP) and thrombin [17]. Compound (1a) showed the antifungal activity on Botrytis cinerea [18] and especially against COX-2 with an $\mathrm{IC}_{50}$ of $127.6 \mu \mathrm{M}$ [19]. ent-Kaur-16-en-19-oic acid (1a) possesses the anti-Alzheimer and antioxidant effects [20] and showed a remarkable inhibitory activity against mutans streptococci: Streptococcus mutans Ingbritt 1600, S. mutans OMZ175, S. mutans P20, S. mutans P6, S. mutans D1), S. sobrinus 6715, S. sobrinus P7, S. sobrinus S2, S. sobrinus S17), S. cricetus HS-6, S. cricetus P12, S. cricetus $\mathrm{S} 2$ and $S$. cricetus S38 [21]. Acid 1a had strong inhibitory effect on the proliferation of human liver cancer (HLC) cell lines $[22,23]$, is genotoxic and mutagenic in human peripheral blood leukocytes (PBLs), yeast (Saccharomyces cerevisiae) [24], was cytotoxically active $\left(\mathrm{ED}_{50}=17.4 \mu \mathrm{g} / \mathrm{mL}\right.$ against HCT-15 COLADCAR, $\mathrm{ED}_{50}=15.5 \mu \mathrm{g} / \mathrm{mL}$ against UISOSQC-1 and $\mathrm{ED}_{50}=19.5 \mu \mathrm{g} / \mathrm{mL}$ against OVCAR-5) [25]. ent-Kaur-16-en-19-oic acid (1a) inhibited acute carrageeninand $\mathrm{PGE}_{2}$-induced and chronic CFA-induced inflammatory mechanical hyperalgesia [26] and possess the antimicrobial effects against Bacillus cereus and Mycobacterium tuberculosis [27].

15 $\alpha$-Angeloyl-ent-kaur-16-en-19-oic (angeloylgrandifloric) acid (2a) was isolated from aerial parts of Helianthus debilis $[11,28]$, from aerial parts of $H$. simulans [11], from $H$. giganteus and from $H$. angastifolius [29]. This compound was isolated from the inflorescence of H. annuus L. [9], from fresh leaves of H. annuus cv. SH-222 [8] and from the sunflower (H. annuus L.) dry wastes [14]. 
15 $\alpha$-Angeloyl-ent-kaur-16-en-19-oic acid (2a) showed weak antifeedant activity [6], also it is a spontaneous uterine contraction inhibitor (SUCI). In vitro bioassay proved that angeloylgrandifloric acid (2a) inhibited the spontaneous contractions of guinea pig uterine strips ( $\mathrm{SUCI}+$ ) at a concentration of $1.2 \mu \mathrm{g} / \mathrm{mL}$ [30]. This compound showed cytotoxic activities on SF-268, MCF-7 and HepG2 cell lines [4], was cytotoxically active $\left(\mathrm{ED}_{50}=17.4 \mu \mathrm{g} / \mathrm{mL}\right.$ against HCT-15 COLADCAR, $\mathrm{ED}_{50}=15.5 \mu \mathrm{g} / \mathrm{mL}$ against UISO-SQC-1 and $\mathrm{ED}_{50}=19.5 \mu \mathrm{g} / \mathrm{mL}$ against OVCAR-5) [25].

ent-Trachyloban-19-oic acid (3a) was isolated from sunflower (Helianthus annuus L.) [2, 13, 31, 32], from roots of Iostephane heterophylla (Asteraceae) [33], from the stem barks of Croton robustus. [34], and from the hexane extract of Xylopia sericea [35]. The thujanol ester of ent-trachiloban-19-oic acid (4) was isolated from sunflower (H. annuus L.) [36, 37]. The absolute stereochemistry of ent-trachiloban-19-oic acid (3a) has been established by X-ray analysis [31], its biotransformation was studied using Rhizopus stolonifer [35].

Methyl trachyloban-19-oate (3b) exhibited weak cytotoxic activity against gastric carcinoma and colon carcinoma with $\mathrm{ED}_{50}$ of 9.6 and $9.1 \mu \mathrm{g} / \mathrm{mL}$, respectively [34]. ent-Trachyloban-19-oic acid (3a) displayed significant in vivo antiinflammatory activity [32] and it was investigated on several photosynthetic activities in spinach thylakoids. Acid (3a) acts as Hill reaction inhibitor. Compound 3a did not affect photosystem I activity but inhibited uncoupled photosystem II electron flow from $\mathrm{H}_{2} \mathrm{O}$ to DCPIP, and has not effect on electron flow from $\mathrm{H}_{2} \mathrm{O}$ to SiMo, indicating that the site of inhibition of this compound is at the level of $\mathrm{Q}_{\mathrm{A}}-\mathrm{Q}_{\mathrm{B}}[33]$.

\section{Results and discussion}

Because of diterpenoids 1a-3a potential practice interest, we have investigated extracts obtained from sunflower (Helianthus annuus L.) dry wastes by their extraction with different organic solvents. Before we reported its extraction with diethyl ether, but here are inconveniences connected to the use of this solvent (highly flammability and volatility). For this reason we decided to consider following solvents for this purpose: petroleum ether, dichloromethane, acetone, ethanol and toluene. Diethyl ether was used as reference.

In all cases the same amounts $(100 \mathrm{~g})$ of dry plant material were extracted, with the same volume $(750 \mathrm{~mL})$ of solvents. The extractions were performed in a Soxhlet apparatus for 10 consecutive cycles. After solvent removal, all crude extracts were weighted (see Table 1) and divided into neutral and acidic part. For easier identification and quantification of the components by GC-MS analysis, each acidic part was treated with ethereal solution of diazomethane leading to diterpenic methyl esters $\mathbf{1 b}-\mathbf{3 b}$ (Table 1).

Table 1.

The relative content of diterpenic esters (1b-3b) in extracts of sunflower (Helianthus annuus $\mathbf{L}$.) dry wastes.

\begin{tabular}{|c|c|c|c|c|c|c|}
\hline \multirow[b]{2}{*}{ Entry } & \multirow[b]{2}{*}{ Solvent* } & \multirow[b]{2}{*}{ Extract weight } & \multirow[b]{2}{*}{$\begin{array}{c}\text { Acidic part } \\
\text { (g) }\end{array}$} & \multicolumn{3}{|c|}{ Diterpenic acid methyl esther relative content $* * *(\%)$} \\
\hline & & & & $\begin{array}{c}\text { Methyl ent-kaur- } \\
\text { 16-en-19- oate } \\
\text { (1b) }\end{array}$ & $\begin{array}{c}\text { Methyl } \\
15 \alpha \text {-angeloil-ent- } \\
\text { kaur-16-en-19-oate } \\
\text { (2b) }\end{array}$ & $\begin{array}{l}\text { Methyl ent- } \\
\text { trachiloban-19- } \\
\text { oate }(3 b)\end{array}$ \\
\hline 1. & Petroleum ether & 1.583 & 0.839 & 8.0 & 0 & 1.0 \\
\hline 2. & Dichloromethane & 2.572 & 1.261 & 12.0 & 0 & 2.0 \\
\hline 3. & Acetone & 3.138 & 1.568 & 17.0 & 0.5 & 4.0 \\
\hline 4. & Ethanol & 5.043 & 2.571 & 21.0 & 1.0 & 6.0 \\
\hline 5. & Toluene & 2.820 & 1.466 & 17.0 & 0.5 & 5.0 \\
\hline 6. & Diethyl ether & 5.082 & 2.592 & 22.0 & 0.5 & 8.0 \\
\hline
\end{tabular}

* A volume of $750 \mathrm{~mL}$ of solvent was used.

** The extract weight obtained from $100 \mathrm{~g}$ of sunflower dry wastes.

*** Determined on the basis of GC-MS data.

GC-MS analyses have been recorded on an Agilent 7890A Gas Chromatograph with 5975C Mass Selective Detector (GC-MSD) equipped with split/splitless injector and HP-5ms capillary column $(30 \mathrm{~m} / 0.25 \mu \mathrm{m})$. The results of diterpenoids (1b-3b) chromatographic and spectral (MS) identification are presented Table 1 and were compared with those obtained before $[13,14]$.

According to these data the predominant component of all extracts is ent-kaur-16-en-19-oic acid (1a). The largest quantities of this compound were found in diethyl ether and ethanol extracts, 22 and $21 \%$ respectively, and lowest in petroleum ether extract $(0 \%)$. The highest content (1\%) of 15 $\alpha$-angeloil-ent-kaur-16-en-19-oic acid (2a) was detected in the ethanol extract, while the ent-trachiloban-19-oic acid (3a) showed the highest content (8\%) in the diethyl ether extract. 
In such a way, considering the results presented in Table 1, we came to the conclusion that the most recommended solvent for efficient diterpenoids 1a-3a extraction is ethanol, which is environmentally friendly, industrial applicable and less flammable then diethyl ether.

\section{Conclusion}

The content of known tetra- and pentacyclic diterpenoids in extracts obtained from sunflower (Helianthus annuus L.) dry wastes using different organic solvents has been studied. It was established that the largest quantity of ent-kaur16-en-19-oic acid is obtained when ethanol and diethyl ether are used for extraction.

\section{Acknowledgment}

This research was supported by the bilateral Project ASM - FCFRB № 13.820.18.03/BFof 04.04. 2013.

\section{References}

[1] Helliwell, C. A.; Chandler, P. M.; Poole, A.; Dennis, E. S.; Peacock, W. J. Proc. Natl. Acad. Sci. U. S. A. 2001, 98, pp. 2065-2070.

[2] Pyrek, J. St. Tetrahedron, 1970, 26, pp. 5029-5032

[3] Elliger, C. A.; Zinkel, D. F.; Chan, B. G.; Waiss Jr., A. C. Experientia, 1976, 32, pp 1364-1366.

[4] Morris, B. D.; Foster, S. P.; Grugel, S.; Charlet, L. D. J. Chem. Ecol., 2005, 31, pp. 89-102.

[5] Mitscher, L. A.; Rao, G. S. R.; Veysoglu, T.; Drake, S.; Haas, T. J. Nat. Prod., 1983, 46, pp. 745-746.

[6] Mullin, C. A.; Alfatafta, A. A.; Harman, J. L.; Everett, S. L. and Serino, A. A. J. Agric. Food Chem., 1991, 39, pp. 2293-2299.

[7] Gao, Y.; Zheng, C.-D.; Li, Y.; Fan, C.; Tu, G.-H.; Gao, J.-M. Chem. Nat. Compd., 2008, 44, pp. $773-775$.

[8] Macías, F. A.; López, A.; Varela, R. M.; Torres, A.; Molinillo, J. M. G. J. Chem. Ecol., 2008, 34, pp. 65-69.

[9] Suo, M. R.; Tian, Z.; Yang, J. S.; Lu, Y.; Wu, L.; Li, W. Acta Pharm. Sinica, 2007, 42, pp. 166-170.

[10] Bohlmann, F.; Jakupovic, J.; King, R. M.; Robinson, H. Phytochemistry, 1980, 19, pp. 863-868.

[11] Herz, W.; Kulanthaivel, P.; Watanabe, K. Phytochemistry, 1983, 22, pp. 2021-2025.

[12] Herz, W.; Kulanthaivel, P. Phytochemistry, 1984, 23, pp. 1453-1459.

[13] Ungur, N.; Grinco, M.; Kulcițki, V.; Barba, A.; Bîzîcci, T.; Vlad, P. F. Chem. J. Mold. 2008, 4 (2), pp. $106-109$.

[14] Grinco, M.; Chetraru, O.; Kulciţki, V.; Barba, A.; Boico, A.; Vlad, P. F.; Ungur, N. Chem. J. Mold. 2010,5 (1), pp. 106-108.

[15] Na, M. K.; Oh, W, K.; Kim, Y. H.; Cai, X. F.; Kim, S. H.; Kim, B. Y.; Ahn, J. S. Bioorg. Med. Chem. Lett., 2006, 16, pp. 3061-3064.

[16] Fatope, M. O.; Audu, O. T.; Takeda, Y.; Zeng, L.; Shi, G.; Shimada, H.; McLaughlin, J. L. J. Nat. Prod., 1996, 59, pp. 301-303.

[17] Diderot, N. T.; Silvere, N.; Yasin, A.; Zareen, S.; Fabien, Z.; Etienne, T.; Choudhary, M. I.; Rahman, A.-U. Biosci. Biotech. Biochem., 2005, 69, pp. 1763-1766.

[18] Cotoras, M.; Folch, C.; Mendoza, L. J. Agric. Food Chem., 2004, 52, pp. 2821-2826.

[19] Dang, N. H.; Zhang, X. F.; Zheng, M. S.; Son, K. H.; Chang, N. W.; Kim, H. P.; Bae, K. H.; Kang, S. S. Arch. Pharm. Res., 2005, 28, pp. 28-33.

[20] Jung, H. A.; Lee, E. J.; Kim, J. S.; Kang, S. S.; Lee, J.-H.; Min, B.-S.; Choi, J. S. Arch. Pharm. Res., 2009, 32, pp. 1399-1408.

[21] Yatsuda, R.; Rosalen, P. L.; Cury, J. A.; Murata, R. M.; Rehder, V. L. G.; Melo, L. V.; Koo, H. J. Ethnopharmacol., 2005, 97, pp. 183-189.

[22] Hsieh, T. J.; Wu, Y. C.; Chen, S. C.; Huang, C. S.; Chen, C. Y. J. Chin. Chem. Soc., 2004, 51, pp. 869-876.

[23] Zhang, Y. H.; Peng, H. Y.; Xia, G. H.; Wang, M. Y.; Han, Y. Acta Pharmacol. Sin., 2004, 25, pp. $937-942$.

[24] Cavalcanti, B. C.; Ferreira, J. R. O.; Moura, D. J.; Rosa, R. M.; Furtado, G. V.; Burbano, R. R.; Silveira, E. R.; Lima, M. A. S.; Camara, C. A. G.; Saffi, J.; Henriques, J. A. P.; Rao, V. S. N.; Costa-Lotufo, L. V.; Moraes, M. O.; Pessoa, C. Mutation Res./ Gen. Toxicol. Environm. Mutag., 2010, 70, pp. 153-63.

[25] Rios, M. Y.; Leon, I. Chem. Nat. Compd., 2006, 42, pp. 497-498.

[26] Mizokami, S. S.; Arakawa, N. S.; Ambrosio, S. R.; Zarpelon, A. C.; Casagrande, R.; Cunha, T. M.; Ferreira, S. H.; Cunha, F. Q.; Verri, Jr., W. A. J. Nat. Prod., 2012, 75, pp. 896-904.

[27] Wilkens, M.; Alarcón, C.; Urzúa, A.; Mendoza, L. Planta Med., 2002, 68, pp. 452-454.

[28] Ohno, N.; Mabry, T. J.; Zabelt, V.; Watson, W. H. Phytochemistry, 1979, 18, pp. 1687-1689.

[29] Bohlmann, F.; Jakupovic, J.; King, R. M.; Robinson, H. Phytochemistry, 1980, 19, pp. 863-868.

[30] Lu, Z.-Z.; Xue, H.-Z.; Tu, Z.-B.; Konno, C.; Waller, D. P.; Soejarto, D. D.; Cordell, C. A.; Fong, H. H. S. J. Nat. Prod., 1987, 50, pp. 995-997.

[31] Sanni, S. B.; Behm, H.; Garcia-Granda, S.; Beurskens, P. T.; Moers, F. G. J. Crystallogr. Spectrosc. Res., 1990, 20, pp. 483-489. 
[32] Diaz-Viciedo, R.; Hortelano, S.; Giron, N.; Masso, J. M.; Rodriguez, B.; Villar, A.; De las Heras, B. Biochem. Biophys. Res. Commun., 2008, 369, pp. 761-766.

[33] Hernandez-Terrones, M. G.; Aguilar, M. I.; Diaz, B. K.; Lotina-Hennsen, B. Pestic. Biochem. Physiol., 2003, 77, pp. 12-17.

[34] Ngamrojnavanich, N.; Tonsiengsom, S.; Lertpratchya, P.; Roengsumran, S.; Puthong, S.; Petsom, A. Arch. Pharm. Res., 2003, 26, pp. 898-901.

[35] Silva, E. A.; Takahashi, J. A.; Oliveira, A. B. J. Braz. Chem. Soc., 2002, 13, 101-105.

[36] Pyrek, J. St. J. Nat. Prod., 1984, 47, pp. 822-827.

[37] For review see: Fraga, M. M. Phytochem. Anal., 1994, 5, pp. 49-56. 